\title{
PERBANDINGAN EKSTRAKSI TEKSTUR CITRA UNTUK PEMILIHAN BENIH KEDELAI DENGAN METODE STATISTIK ORDE I DAN STATISTIK ORDE II
}

\author{
Yampi R. Kaesmetan \\ Program Studi Teknik Informatika S1 STIKOM Uyelindo \\ Jl. Perintis Kemerdekaan No. 1- Kayu Putih, Kupang-NTT \\ Email:kaesmetanyampi@gmail.com
}

\begin{abstract}
The problem in determining the selection of soybean seeds for replanting, especially in East Nusa Tenggara is still an important issue. The thing that affects the quality of soybean seeds is found broken seeds, dull seeds, dirty seeds, and broken seeds due to the process of drying and shelling. Determination of soy bean quality is usually done manually by visual observation. The manual system takes a long time and produces products with inconsistent quality due to visual limitations, fatigue, and different perceptions of each observer. This research was conducted using comparison of image texture extraction with statistical methods of order I (color moment) and order II statistics (GLCM) for soy bean selection. Order I statistics (color moment) show the probability of the appearance of the value of the gray degree of pixels in an image, while the order II statistics (GLCM) show the probability of a neighborhood relationship between two pixels that form a cohesion matrix from the image data. This research is expected to help the classification process in determining soybean seeds. The k-Nearest Neighbor (k-NN) algorithm used in previous studies to classify the image objects to be examined. The results of this study were successfully conducted using k-Nearest Neighbor (k-NN) with euclidean distance and $\mathrm{k}=1$ with the results of color moment extracts getting the highest accuracy of $88 \%$ and the results of GLCM feature extraction for homogeneity characteristics of $75.5 \%$, correlations of $78.67 \%$, contrast is $65.75 \%$ and energy is $63.83 \%$ with an average accuracy of $70.93 \%$.
\end{abstract}

Keywords: Soybean Seeds, Digital Image, GLCM, Color Moment, Texture.

\section{PENDAHULUAN}

Kacang kedelai berasal dari genus Glycine kelas Glycine max merupakan komoditas pangan yang sangat dekat dengan masyarakat Indonesia dan menjadi salah satu target dalam pencapaian swasembada pangan, Kacang kedelai merupakan tanaman yang memiliki nilai ekonomi yang tinggi. dan merupakan sumber nabati yang berlimpah di Indonesia dan potensial untuk dikembangkan sebagai food supplement [12]. Dalam kelompok tanaman pangan, kedelai merupakan komoditas terpenting ketiga setelah padi dan Kacang Kedelai. Selain itu, kedelai juga merupakan komoditas palawija yang kaya akan protein. Kedelai segar sangat dibutuhkan dalam industri pangan dan bungkil kedelai dibutuhkan untuk industri pakan [12]. Kedelai berperan sebagai sumber protein nabati yang sangat penting dalam rangka peningkatan gizi masyarakat, karena selain aman bagi kesehatan juga relatif murah dibandingkan sumber protein hewani. Kebutuhan kedelai terus meningkat seiring dengan pertumbuhan jumlah penduduk dan kebutuhan bahan baku industri olahan pangan seperti tahu, tempe, kecap, susu kedelai, tauco, snack. Direktorat Jenderal Tanaman Pangan memperkirakan konsumsi kedelai saat ini sekitar 2,2 juta ton, dan bungkil kedelai sekitar 1,1 juta ton (Ditjentan 2016). Hal ini diperkuat oleh data statistik dari FAO dan BPS, bahwa konsumsi kedelai pada tahun 2014 sebesar 2,18 juta ton, sedangkan produksi dalam negeri baru mencapai 0,72 juta ton. Kekurangannya diimpor sebesar 1,12 juta ton, atau sekitar $61 \%$ dari total kebutuhan (litbang pertanian, 2016). Konsumsi per kapita berfluktuasi tergantung ketersediaan, yaitu dari 4,12 kg pada tahun 1970 menjadi $10,85 \mathrm{~kg}$ pada tahun 2000 dan $7,90 \mathrm{~kg}$ pada tahun 2005, atau secara keseluruhan meningkat rata-rata 
2,3\% per tahun selama 35 tahun terakhir (BPS 2016).

Kendala yang diduga menyebabkan terus menurunnya areal panen kedelai antara lain adalah (litbang pertanian, 2016): Produktivitas yang masih rendah, sehingga kurang menguntungkan dibandingkan komoditas pesaing lainnya (2) Belum berkembangnya industri perbenihan

Keterampilan petani yang masih rendah (4) Rentan gangguan organisme pengganggu tanaman (OPT) (5) Belum berkembangnya pola kemitraan, karena sektor swasta belum tertarik untuk melakukan agribisnis kedelai.

Agar memiliki daya saing yang tinggi, maka arah pengembangan komoditas kedelai dengan memanfaatkan soft computing dalam melakukan seleksi pembenihan. Benih inti merupakan benih yang digunakan untuk menghasilkan benih penjenis (breeder seed/BS). Benih sumber terdiri dari 3 (tiga) kelas yaitu benih penjenis (breeder seed/BS), benih dasar (Foundation Seed/FS/BD) dan benih pokok (stock seed/SS/BP)., Sistem perbenihan formal untuk tanaman kedelai hingga kini belum berjalan sebagaimana yang diharapkan. Sebagai indikasi adalah penggunaan benih bersertifikat untuk tanaman kacang-kacangan masih kurang dari 3\%, kenyataan yang terjadi di lapangan pada saat pemisahan benih biji kedelai setelah panen adalah dengan di keringkan hingga kadar air mencapai 9-10\%, kemudian disimpan dalam kantong plastik tebal. Dalam proses produksi benih kedelai untuk menghasilkan benih bermutu harus melalui prosedur sertifikasi benih mulai dilapangan, uji laboratorium hingga prosessing dan pelabelan

Seringkali benih yang dihasilkan adalah kulit biji berwarna kuning, polong masak berwarna coklat muda dan warna hilum kuning kecoklatan, kebanyakan benih tersebut memiliki tekstur yang mudah pecah atau retak. Untuk mengetahui benih kedelai yang layak dipakai dapat dilakukan dengan cara klasifikasi. Klasifikasi sendiri berarti pembagian data menjadi dua bagian yaitu data tersebut baik atau tidak baik. Dengan adanya klasifikasi maka data benih kedelai yang dihasilkan lebih akurat.

Pengklasifikasian benih kedelai yang layak dan tidak layak dapat dilakukan menggunakan teknik pembelajaran supervised learning. Supervised learning merupakan metode dengan adanya latihan. Penelitian ini menerapkan analisis tekstur dengan ekstraksi ciri menunjukkan bahwa pada ciri mean, skewnees, dan standar deviasi memiliki validasi rata-rata sebesar $88 \%$ dan ekstraksi ciri. Penelitian mengenai sistem klasifikasi kualitas biji Kacang Kedelai berdasarkan tekstur berbasis pengolahan citra digital menggunakan metode ektraksi ciri statistik dan $k$-Nearest Neighbor [6]. Metode $k$-Neaarest Neighbor $(k-\mathrm{NN})$ dapat menghasilkan akurasi yang diharapkan pada sistem klasifikasi kualitas biji Kacang Kedelai. Terbukti dengan menggunkan cityblock distance dapat menghasilkan akurasi 91,85\%. Implementasi $k$ Nearest Neighbor untuk klasifikasi kualitas tembakau menggunakan digital image processing berbasis android [9]. Penelitian ini menerapkan metode $k$-Nearest Neighbor untuk menentukan klasifikasi kualitas daun tembakau dengan tingkat akurasi kebenaran mencapai $77,5 \%$ dengan nilai $\mathrm{k}$ yaitu 3 dengan hasil $82,5 \%$. Perbandingan pengukuran jarak dalam penentuan kualitas benih Kacang Kedelai lokal Pulau Timor dengan $k$-Nearest Neighbor [7]. Penelitian ini menghasilkan akurasi mencapai 93\% sehingga dapat dikatakan metode $k$ Nearest Neighbor dapat mengklasifikasikan dengan benar. Perbandingan hasil sortasi citra menggunakan algoritma $k$-Nearest Neighbor menghasilkan data yang akurat.

Metode $k$-Nearest Neighbor (k-NN) dapat menghasilkan akurasi yang diharapkan pada sistem klasifikasi kualitas biji Kacang Kedelai. K-Nearest Neighbor (k-NN) merupakan metode supervised learning yang melakukan klasifikasi berdasarkan kedekatan jarak suatu data dengan data yang lain [8]. Pada algoritma $k$-NN jarak dari suatu vektor data ke vektor data yang lain dapat dihitung. Nilai jarak digunakan sebagai nilai kedekatan atau kemiripan antara data testing dengan dataset. Metode ini memiliki tingkat keakuratan yang cukup tinggi karena data yang masuk akan diklasifikasikan berdasarkan kemiripan ciri yang ada dari data yang akan masuk dan dikalsifikasikan berdasarkan kemiripan ciri yang ada dari data sebelumnya yang sudah diklasifikasikan [4]. Dalam penelitian ini akan menggunakan metode $k$-NN dengan membandingkan jarak euclidean dan minkowsky untuk menentukan kualitas benih kedelai apakah layak digunakan atau tidak layak digunakan, dilihat dari tekstrur benih kedelai yang akan diteliti menggunakan ekstraksi ciri statistik orde I dan memakai ciri mean, standar deviasi, dan skewnees sehingga 
memudahkan untuk menentukan mana benih kedelai yang layak.

Penelitian ini akan melakukan ekstraksi ciri dengan pengukuran jarak yang akan digunakan yaitu euclidean dan minkowsky dalam perhitungan penentuan kualitas benih kedelai yang baik dan layak untuk digunakan oleh petani dengan tingkat akurasi yang dihasilkan akurat. Informasi tentang tingkat akurasi benih kedelai inilah yang menentukan penelitian ini berhasil dilakukan atau tidak.

\section{TINJAUAN PUSTAKA}

\section{Metode Pengembangan Sistem}

Metodologi adalah suatu cara kerja yang digunakan untuk membangun suatu sistem yang baru. Sistem klasifikasi kualitas benih kedelai terdiri dari blok utama yaitu akuisisi citra, praproses, ekstraksi ciri warna, hitung jarak dan klasifikasi. Sampel diolah oleh sistem klasifikasi dan hasilnya berupa klasifikasi kualitas benih kedelai. Sistem akan dirancang menggunakan tampilan graphical user interface sehingga tampilannya lebih menarik dan mudah untuk digunakan.

\section{Prosedur Analisis data}

Prosedur analisis data dalam penelitian ini digambarkan seperti pada gambar 1 .

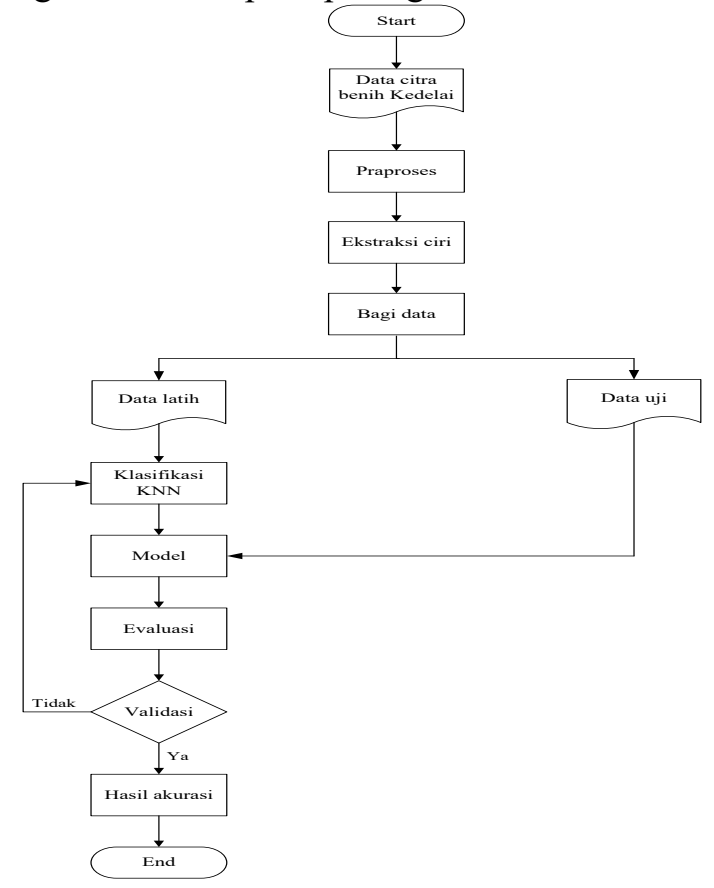

Gambar 1. Prosedur analisis data

Berikut penjelasan mengenai prosdur analisis data yaitu sebagai berikut:

a. Data citra benih kedelai
Tahap awal sebelum prosesan data citra adalah tahap pengumpulan data. Data citra yang digunakan dalam penelitian ini adalah citra benih kedelai yang diambil menggunakan kamera digital, dan di simpan dengan format file *.jpg. citra awal ditampilkan pada gambar 2.

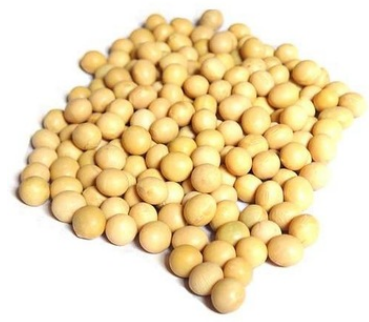

Gambar 2. Citra benih kedelai

b. Praproses

Tahap praproses adalah tahap untuk mentranformasi data ke suatu format yang prosesnya lebih mudah dan efektif untuk mendapatkan nilai yang lebih aktual dan mengurangi komputasi warna dalam skala besar. Pada tahap ini dilakukan cropping citra secara manual dalam sistem kemudian dilakukan pengubahan dimensi dari citra awal untuk mendapatkan ukuran yang lebih kecil dan data yang akan diproses lebih spesifik karena mengurangi data yang tidak terpakai. Setelah tahap cropping dilakukan dengan ukuran citra baru yaitu $100 \times 100$ piksel, tahap selanjutnya mengubah data citra hasil cropping ke skala keabuan agar dimensi matriks citra menjadi lebih kecil dan untuk mendapatkan citra biner.

c. Ekstraksi ciri

Ekstraksi ciri adalah proses pengambilan ciri-ciri tekstur yang terdapat pada objek di dalam citra. Pada proses ini objek di dalam citra dihitung properti-properti objek yang berkaitan sebagai ciri. Ekstraksi ciri merupakan metode pengambilan ciri yang didasarkan pada karakteristik histogram citra. Histogram citra menunjukkan probabilitas kemunculan nilai derajat keabuan piksel pada suatu citra. Dari nilai-nilai pada histogram yang dihasilkan, dapat dihitung beberapa parameter ciri. Ekstraksi ciri menggunakan color moment menunjukan probabilitas kemunculan nilai derajat keabuan piksel pada suatu matriks. Matriks citra yang sebelumnya berukuran 100 x 100 akan diubah menjadi vektor berukuran 1 x 3 dengan proses ekstraksi ciri menggunakan citra HSV (high saturation value). Pada tahapan ini juga citra akan menghitung nilai dari masing-masing ciri. Ciriciri yang digunakan pada ekstraksi ini antara lain mean, standar deviasi, dan skewnees. 
Banyaknya data yang digunakan adalah 100 data citra kedelai sehingga yang dihasilkan adalah 100 vektor. Vektor inilai yang menjadi dataset masukkan untuk proses klasifikasi. Berikut digambarkan diagram alir untuk ekstraksi ciri pada gambar 3 .

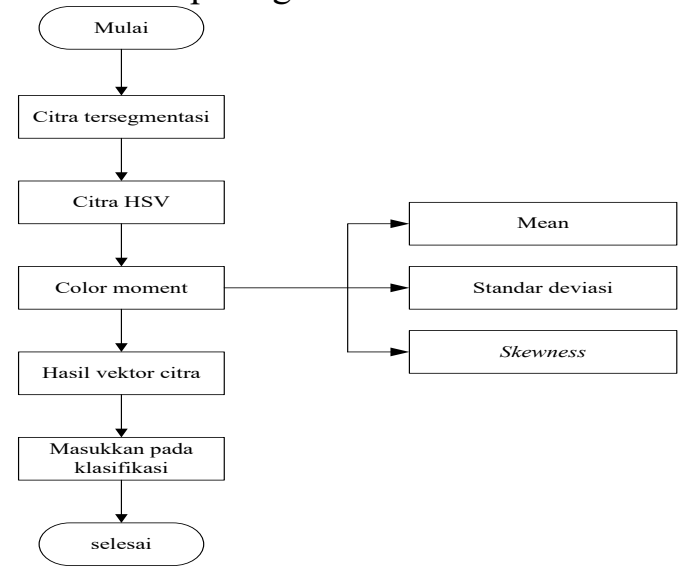

Gambar 3. Blok diagram color moment

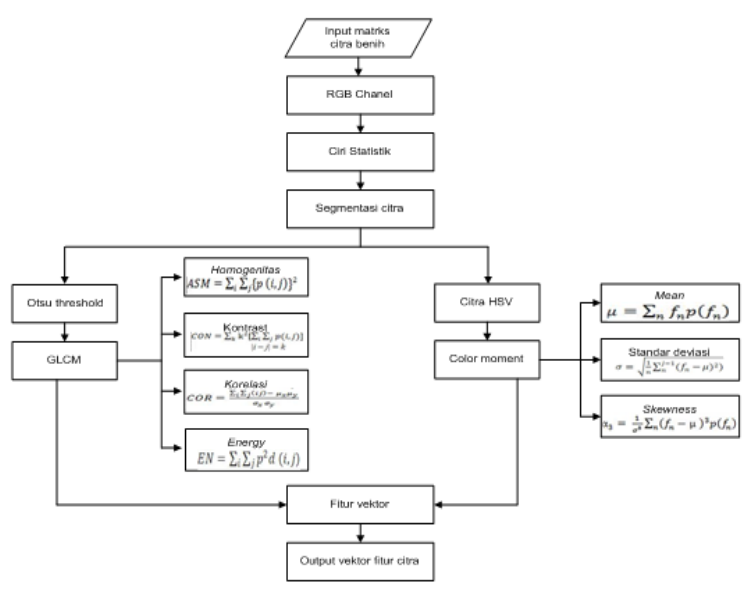

Gambar 4. Blok diagram Ekstraksi Ciri

\section{d. Bagi data}

Data citra yang telah melalui tahap praproses dan ekstraksi ciri kemudian dibagi dengan $k$-fold. Pada tahap ini data citra dibagi menjadi dua bagian, yaitu data uji dan data latih. Data latih digunakan untuk melakukan pelatihan statistic textures, sedangkan data uji digunakan untuk pengujian $K$-NN. Citra benih kedelai yaitu ada 100 citra benih. $k$ yang digunakan adalah 10-fold, maka metode yang digunakan adalah 10-fold cross validation. Untuk pembagian dataset dibagi menjadi data latih dan data uji, untuk 10-fold pembagian datanya $90 \%$ data latih dan $10 \%$ data uji. Berikut ini adalah gambar tentang cross validation untuk pembagian data di gambar 4.

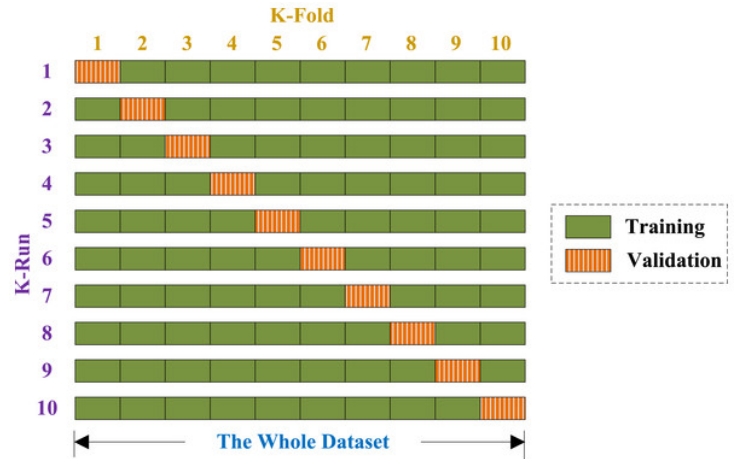

Gambar 5. 10-fold cross validation

e. Klasifikasi dengan $k$-Nearest Neighbor

Klasifikasi dilakukan dengan data masukkan berupa matriks komposisi dari proses ekstraksi ciri yang telah dilakukan sebelumnya, proses klasifikasi akan menghasilkan dua kelas yaitu kelas layak dan kelas tidak layak. K-Nearest Neighbor (K-NN) adalah metode pengukuran kemiripan yang sederhana. Penelitian ini menggunakan 2 cara dalam pengukuran kemiripan yaitu berdasarkan euclidean dan minkowski. Analisis yang dilakukan pada $K$-NN adalah pengaruh penggunaan pengukuran kemiripan dan nilai $k$ yang digunakan terhadap akurasi sistem dalam mengklasifikasikan kualitas benih kedelai.

Langkah-langkah dalam pengklasifikasian menggunakan $K$-NN antara lain adalah menginput vektor hasil ekstraksi ciri tekstur kemudian menentukan jumlah tetangga terdekat $(k), k$ yang digunakan 1,3, dan 5 . Selanjutnya menghitung jarak test data ke data training menggunakan jarak euclidean dan minkowski. Kemudian menentukan kelompok test data berdasarkan kelas mayoritas pada $k$.

f. Evaluasi

Evaluasi penentuan kualitas benih kedelai berdasarkan tekstur citra, dilakukan untuk memprediksi seberapa baik klasifikasi label pada kelas tupel. Metode ini menggunakan tabel matriks seperti pada tabel 1 jika data set hanya terdiri dari dua kelas, kelas yang satu dianggap sebagai positif dan yang lainnya negatif. Dengan ketentuan true positive (TP) adalah tupel positif yang bernilai benar pada label klasifikasi. True negative (TN) adalah tupel negative bernilai benar pada label klasifikasi. False negative (FN) adalah tupel positif yang disalah artikan sebagai negatif. Sensitivitas dan spesifitas dapat digunakan untuk penentuan label tupel, sensitivitas disebut juga sebagai tupel positif yang bernilai benar, sedangkan spesifitas adalah tupel negatif yang bernilai benar. Cara mencari nilai 
sensitivitas dan spesifitas dapat dirumuskan dengan (Han et al., 2012).

Sensitivitas $=\frac{T P}{T P+F N}$

Spesivitas $=\frac{T N}{T N+F P}$

Akurasi $=\frac{\sum \text { data yang diprediksi benar }}{\sum \text { seluruh data }} \times 100 \%$

Keterangan:

$\mathrm{TP}=$ jumlah true positive

$\mathrm{TN}=$ jumlah true negative

$\mathrm{FP}=$ jumlah false positive

$\mathrm{FN}=$ jumlah false negative

Tabel 1. Confusion matrix

\begin{tabular}{lll}
\hline Klasifikasi yang benar & $\begin{array}{l}\text { Diklasifikasikan } \\
\text { sebagai }\end{array}$ \\
\cline { 3 - 3 } & - & \multicolumn{1}{c}{+} \\
\hline+ & true & false negatives \\
& $\begin{array}{l}\text { positives } \\
\text { false } \\
\text { positives }\end{array}$ & true negatives \\
- & \\
\hline
\end{tabular}

\section{HASIL DAN PEMBAHASAN}

Fitur yang digunakan terkait dengan ekstraksi ciri benih kedelai dengan analisis ekstraksi ciri tekstur citra dengan color moment yaitu mean, standar deviasi dan skewness. Klasifikasi benih kedelai dikembangkan dengan Matlab R2010b. Benih kedelai dibagi dalam 2 kelas yaitu kelas layak dan kelas tidak layak.

\section{Basis Data Benih Kedelai}

Citra benih kedelai yang diambil pada penelitian ini adalah sebanyak 100 data citra benih kedelai, yang nantinya terbagi 90 citra untuk data latih dan 10 citra untuk data uji. Dimensi citra awal 2432 x 2112 pixel dan disimpan dengan format file JPG. Citra yang akan dijadikan sampel akan di resize menjadi 300 x 300 pixel, data citra ini dipanggil kedalam matlab untuk mendapatkan data matriks yang akan diolah.

\section{Praproses}

Tahap ini dilakukan untuk mendapatkan akurasi data dari citra benih Kacang Kedelai yang akan dijadikan sampel, proses ini untuk mencegah terjadinya ketidakakuratan data untuk mendapat data yang aktual. Citra RGB atau biasa disebut true color adalah citra yang dapat mempresentasikan warna objek menyerupai aslinya dengan mengkombinasikan ketiga warna dasar yaitu red $(\mathrm{R})$, green $(\mathrm{G})$ dan blue $(\mathrm{B})$. Tiap piksel dari citra RGB memiliki tiga kanal yang mewakili tiap komponen warna dasar (Gonzales, 2007). Citra keabuan merupakan citra digital yang hanya memiliki satu nialai kanal pada setiap pikselnya, dengan kata lain nilai bagian red $=$ green $=$ blue . Nilai tersebut digunakan untuk menunjukan tingkat intensitas. Warna yang dimiliki tiga grayscale adalah warna keabuan dengan berbagai tingkatan dari hitam hingga putih. Citra grayscale dapat diperoleh dari citra RGB. Nilai intensitas citra grayscale (keabuan) dihitung dari nilai intensitas citra RGB dengan menggunakan persamaan:

Nilai Keabuan $=\alpha R+\beta G+\delta B /(\alpha+\beta+\delta) \ldots \ldots .(1)$

Dengan nilai $\alpha=$ nilai untuk $\mathrm{R}(0,35), \beta=$ nilai untuk $\mathrm{G}(0,25), \delta=$ nilai untuk $\mathrm{R}(0,4)$, sehingga nilai $\alpha+\beta+\delta=1$. Citra yang telah diubah ke skala keabuan akan diproses untuk menghilangkan noise dengan menggunakan median filter dengan mencari rata-rata dari nilai piksel citra yang telah diurutkan dengan persamaan:

$f(y, x)=$ median $_{(\mathrm{p}, \mathrm{q}) \text { esyx }}(g(p, q))$......

Dimana $f(y, x)=$ bobot hasil pada posisi $(y, x), g(p, q)=$ elemen matrik kernel gauss pada posisi $(p, q)$.

\section{Citra Digital}

Citra digital dapat dinyatakan sebagai suatu fungsi dua dimensi $f(x, y)$, dengan $x$ maupun $y$ adalah posisi koordinat sedangkan $f$ merupakan amplitudo pada posisi $(x, y)$ yang sering dikenal sebagai intensias atau grayscale (Purnomo, 2010). Nilai intensitas diskrit mulai dari 0 sampai 255 , begitu pula nilainilai $x, y$, dan $f(x, y)$ harus berada pada jangkauan atau range tertentu yang jumlahnya terbatas. Citra yang dicapture oleh kamera dan telah dikuantisasi dalam bentuk diskrit dinamakan citra digital. Citra digital tersusun dari sejumlah nilai tingkat keabuan yang disebut piksel pada posisi tertentu.

Secara matematis persamaan untuk fungsi intensitas $f(x, y)$ adalah: 
$0 \leq \mathrm{f}(\mathrm{x}, \mathrm{y})<\infty$

\begin{tabular}{lllllll}
2 & 8 & 7 & 9 & 1 & 8 & 6 \\
4 & 0 & 6 & 4 & 7 & 0 & 6 \\
3 & 5 & 7 & 3 & 0 & 5 & 4 \\
0 & 6 & 4 & $\mathrm{~T}$ & 5 & 3 & 0 \\
5 & 5 & 0 & 7 & 2 & 8 & 7 \\
1 & 7 & 7 & $\$$ & 4 & 0 & 6 \\
6 & 2 & 3 & 7 & 5 & 7 \\
\multicolumn{5}{c}{ T=titik yang akan diproses }
\end{tabular}

Contoh pixel citranya adalah sebagai berikut:

$\begin{array}{lllllll}2 & 8 & 7 & 9 & 1 & 8 & 6 \\ 4 & 0 & 6 & 4 & 7 & 0 & 6 \\ 3 & 5 & 7 & 3 & 0 & 5 & 4 \\ 0 & 6 & 4 & 0 & 5 & 3 & 0 \\ 5 & 5 & 0 & 7 & 2 & 8 & 7 \\ 1 & 7 & 7 & 6 & 4 & 0 & 6 \\ 6 & 2 & 3 & 7 & 3 & 5 & 7\end{array}$

Sebelum diurutkan:

28791864064706357305406405305507287177640 66237357

Sesudah diurutkan:

00000001122233333444445555566666667777777778889

\section{Nilai mediannya adalah 5}

\section{Ekstraksi Ciri}

Pada proses ini citra yang telah dilakukan tahap praproses akan di ekstraksi ciri tekstur menggunakan color moment. Color moment menunjukan probabilitas kemunculan nilai derajad keabuan piksel pada suatu citra. Matriks citra yang sebelumnya didapatkan dari tahap praproses berukuran 300 x 300 akan diubah menjadi vector berukuran $3 \times 3$ dengan proses ekstraksi ciri menggunakan citra HSV. Pada tahapan ini juga citra akan menghitung nilai dari masing-masing ciri. Ciri-ciri yang digunakan pada ekstraksi ini antara lain mean, standar deviasi, dan skewness. Banyaknya data yang digunakan adalah 100 data citra benih kedelai sehingga yang dihasilkan adalah 100 vektor. Vektor inilah yang menjadi dataset masukkan untuk proses klasifikasi.

\section{Evaluasi}

Evaluasi dari penelitian dilakukan menggunakan confusion matrix, confusion matrix digunakan untuk menghitung spesifitas, sensivitas dan akurasi. Akan menampilkan hasil perhitungan sensivitas, nilai sensivitas memberikan hasil yang paling besar adalah pada $k=3$ dengan jarak minkowski pada fitur mean, nilai sensivitas mencapai $90.3 \%$ ini menunjukkan bahwa sitem dapat mampu mengenali semua data positif tidak sebagai negatif. Nilai spesifitas memberikan hasil paling besar adalah pada $k=3$ dengan jarak minkowski pada fitur mean, nilai spesifitas mencapai $78.4 \%$ ini menunjukkan bahwa sistem secara handal mampu mengenali semua data negatif tidak sebagai positif. Sedangkan nilai akurasi yang paling besar adalah pada $k=$ 3 dengan jarak minkowski pada fitur mean, nilai akurasi mencapai $82 \%$ ini menunjukkan bahwa sistem dapat melakukan klasifikasi dengan benar.

Dilihat dari nilai $k$, maka $k=3$ menghasilkan nilai yang paling besar pada fitur ciri mean pada sensivitas, spesifitas, dan akurasi. Hal ini menunjukkan bahwa nilai $k$ yang digunakan dapat melakukan pengklasifikasian dengan baik pada benih yang diteliti.

\section{Antarmuka Sistem}

Antarmuka merupakan media penghubung antar sistem dan pengguna. Pengoperasian sistem akan dimulai pada halaman antarmuka sistem ini, sehingga memudahkan pengguna untuk menggunakan aplikasi ini. Berikut adalah tampilan antarmuka sistem k-NN pada gambar 7 .

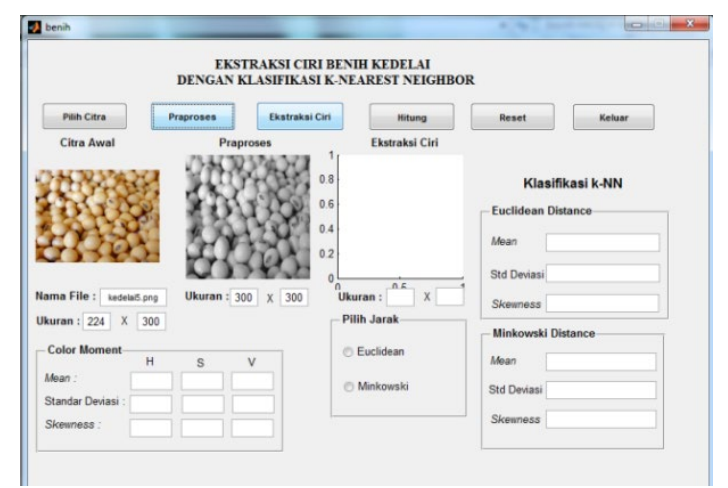

Gambar 7. Antarmuka sistem

Halaman tampilan klasifikasi dengan jarak euclidean adalah halaman yang digunakan untuk menampilkan hasil klasifikasi dari ekstraksi ciri orde I (color moment) dengan menampilkan hasil klasifikasi dari fitur mean, standar deviasi, dan skewnees. Halaman tampilan klasifikasi dengan jarak euclidean dapat dilihat pada gambar 8 . 


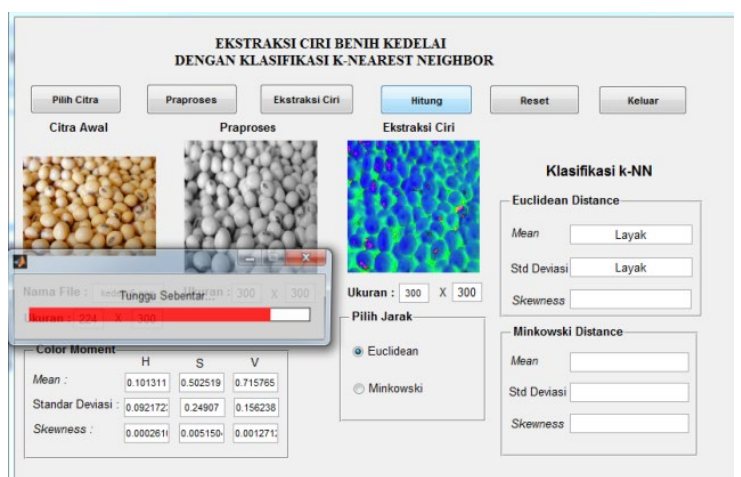

Gambar 8. Tampilan klasifikasi jarak euclidean

Halaman tampilan klasifikasi dengan jarak minkowski

Halaman tampilan klasifikasi dengan jarak minkowski adalah halaman yang digunakan untuk menampilkan hasil klasifikasi dari ekstraksi ciri (color moment) dengan menampilkan hasil klasifikasi dari fitur mean, standar deviasi, dan skewnees. Halaman tampilan klasifikasi dengan jarak minkowski dapat dilihat pada gambar 9 .

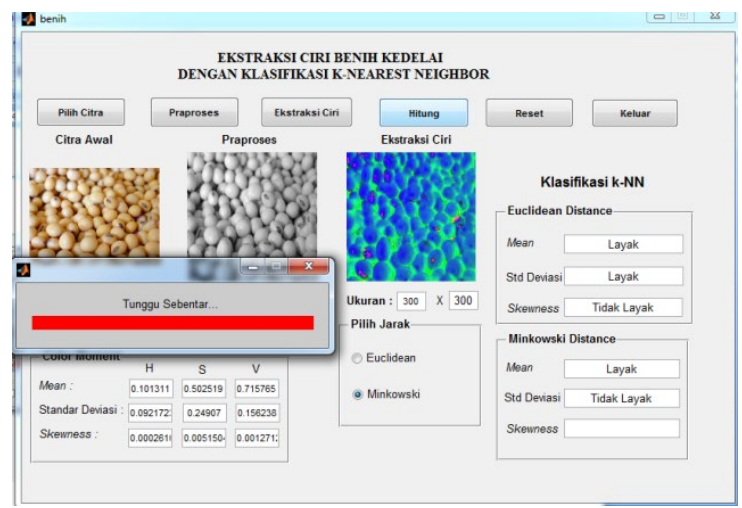

Gambar 9. Halaman tampilan klasifikasi dengan jarak minkowski

\section{Pengujian hasil klasifikasi}

Pengujian akurasi sistem dilakukan dengan mengukur kinerja dari sistem penentuan kualitas benih kacang kedelai berdasarkan tekstur. Pada penelitian ini citra yang diuji adalah citra kacang kedelai. Pengujian ini dilakukan dengan menggunakan klasifikasi $k$-NN (euclidean distance) dengan nilai $\mathrm{k}$ adalah 1, 3 dan 5 . Pengujian dilihat dari sebaik apa classifier memprediksi kualitas benih kacang kedelai yang layak untuk dijadikan benih dan yang tidak layak untuk dijadikan benih. Pengujian dilakukan dengan mencari nilai sensitifitas, spesifisitas dan akurasi dari sistem klasifikasi untuk mengetahui keakuratan dari sistem ini.
Hasil dari pengolahan citra ini adalah pembangkitan data-data numerik dari setiap citra benih Kacang Kedelai tersebut akan dipisahkan menjadi benih Kacang Kedelai layak dan tidak layak. Hasil ratarata pengolahan ekstraksi ciri color moment dapat dilihat pada Tabel 1 berikut ini.

Tabel 1. Hasil rata-rata pengolahan citra benih Kacang Kedelai untuk ciri color moment

\begin{tabular}{lcc}
\hline \multicolumn{1}{c}{ Ciri } & $\begin{array}{c}\text { Nilai rata-rata } \\
\text { benih Kacang } \\
\text { Kedelai layak } \\
\text { tanam }\end{array}$ & $\begin{array}{c}\text { Nilai rata-rata benih } \\
\text { Kacang Kedelai tidak } \\
\text { layak tanam }\end{array}$ \\
\hline Mean & 0.3516 & 0.3347 \\
Standar deviasi & 0.2347 & 0.2189 \\
Skewness & 0.0174 & 0.0126 \\
\hline
\end{tabular}

Dari Tabel 2 dapat dilihat bahwa ciri color moment yang paling tinggi rataratanya adalah mean karena memiliki nilai rata-rata benih kacang kedelai layak sebesar 0.3516 dan benih kacang kedelai tidak layak sebesar 0.3347 hal ini berarti ukuran dispersi (penguraian atau pembiasan warna) dari suatu citra yang dimiliki cukup tinggi. Sedangkan ciri dengan nilai rata-rata rendah adalah pada skewness karena memiliki nilai rata-rata benih Kacang Kedelai layak sebesar 0.0174 dan benih Kacang Kedelai tidak layak sebesar 0.0126, hal ini berarti pengukuran tingkat kemencengan relatif dari suatu citra kurang.

\section{Karakteristik ciri mean pada citra Benih Kacang Kedelai layak tanam dan tidak layak tanam}

Rata-rata dari ciri mean adalah 0.3516 untuk benih Kacang Kedelai layak tanam dan 0.3347 untuk benih Kacang Kedelai tidak layak tanam. Berdasarkan rata-rata pada benih layak tanam dan tidak layak tanam maka rentang nilainya tidak terlalu jauh yakni 0.0269, padahal perbedaan antara nilai ciri mean akan memudahkan program dalam membedakan jenis benih layak tanam dan tidak layak tanam.

\section{Karakteristik Ciri standar deviasi pada Citra Benih Kacang Kedelai Layak Tanam dan tidak Layak Tanam}

Rata-rata dari ciri standar deviasi adalah 0.2347 untuk benih kacang kedelai layak tanam dan 0.2189 untuk benih 
kacang kedelai tidak layak tanam. Berdasarkan rata-rata pada benih layak tanam dan tidak layak tanam maka rentang nilainya tidak terlalu jauh yaitu 0.0158 , padahal perbedaan antara nilai ciri standar deviasi akan memudahkan program dalam membedakan jenis benih layak tanam dan tidak layak tanam.

\section{Karakteristik ciri skewness pada citra Benih Kacang Kedelai layak tanam dan tidak layak tanam}

Rata-rata dari ciri skewness adalah 0.0174 untuk benih kacang kedelai layak tanam dan 0.0126 untuk benih kacang kedelai tidak layak tanam. Berdasarkan rata-rata pada benih layak tanam dan tidak layak tanam maka rentang nilainya tidak terlalu jauh yaitu 0.0048, padahal perbedaan antara nilai ciri skewness akan memudahkan program dalam membedakan jenis benih layak tanam dan tidak layak tanam.

Pada penelitian ini digunakan klasifikasi $k$-NN dengan jarak yang digunakan adalah euclidean distance dan nilai $\mathrm{k}$ yang dipakai adalah 1 dan menggunakan ekstraksi ciri orde I atau color moment. Skenario data yang digunakan adalah skenario empat fold validasi silang (4-fold cross validation). Hasil akurasi yang didapatkan dari klasifikasi $k$-NN untuk ciri mean adalah $90 \%$, standar deviasi adalah $88 \%$ dan skewness adalah 86\%. Validasi diulang satu kali untuk setiap ciri dan diambil rataratanya. Dari data hasil validasi didapatkan bahwa ekstraksi citra untuk membedakan benih Kacang Kedelai yang layak dan tidak layak sudah layak untuk digunakan. Untuk lebih jelasnya bisa dilihat pada perbedaan pengujian sensitivitas dan spesifisitas masing-masing ciri yang ditampilkan pada Tabel 2 sampai Tabel.

Tabe 12. Pengujian sensitivitas dan spesivisitas color moment citra benih Kacang Kedelai

\begin{tabular}{lccc}
\hline \multicolumn{1}{c}{ Ciri } & Sensitivitas & Spesifisitas & Akurasi \\
\hline Mean & $92.42 \%$ & $80.83 \%$ & $90 \%$ \\
Standar deviasi & $88.67 \%$ & $85 \%$ & $88 \%$ \\
\hline
\end{tabular}

\begin{tabular}{llll}
\hline Skewness & $87.76 \%$ & $78.33 \%$ & $86 \%$ \\
Rata-rata & $\mathbf{8 9 . 6 1 \%}$ & $\mathbf{8 1 . 3 8 \%}$ & $\mathbf{8 8 \%}$ \\
\hline
\end{tabular}

Dari Tabel 3, dapat dilihat bahwa pada ciri mean sensitivitas sebesar $92.42 \%$, spesifisitas sebesar 80.83\%, akurasi sebesar 90\%, ciri standar deviasi sensitivitas sebesar $88.67 \%$, spesifisitas sebesar $85 \%$, akurasi sebesar $88 \%$ dan ciri skewness sensitivitas sebesar $87.76 \%$, spesifisitas sebesar 78.33\%, akurasi sebesar $86 \%$. Dari ke 3 ciri tersebut memiliki nilai rata-rata untuk sensitivitas yaitu $89.61 \%$, nilai rata-rata untuk spesifisitas yaitu $81.38 \%$ dan nilai rata-rata untuk akurasi yaitu $88 \%$ sehingga bisa dikatakan bahwa teknik klasifikasi dengan $k$-NN sudah memberikan hasil yang baik dalam mengklasifikasikan citra dengan teksur menggunakan ciri color moment.

Hasil rata-rata pengolahan ekstraksi ciri GLCM dapat dilihat pada Tabel 3 berikut ini.

Tabel 3. Hasil rata-rata pengolahan citra benih Kacang Kedelai untuk ciri GLCM

\begin{tabular}{lcc}
\hline \multicolumn{1}{c}{ Ciri } & $\begin{array}{c}\text { Nilai rata-rata } \\
\text { Benih Kacang } \\
\text { Kedelai layak } \\
\text { tanam }\end{array}$ & $\begin{array}{c}\text { Nilai rata-rata Benih } \\
\text { Kacang Kedelai tidak } \\
\text { layak tanam }\end{array}$ \\
\hline Homogeneity & 0.9241 & 0.9243 \\
Correlation & 0.9967 & 0.9969 \\
Contrast & 0.4589 & 0.2903 \\
Energy & 0.0982 & 0.1056 \\
\hline
\end{tabular}

Dari Tabel 4 dapat dilihat bahwa ciri tekstur yang paling tinggi rata-ratanya adalah korelasi karena memiliki nilai ratarata benih Kacang Kedelai layak sebesar 0.9967 dan benih Kacang Kedelai tidak layak sebesar 0.9969 hal ini berarti ukuran ketergantungan linear derajad keabuan citra sehingga memberikan petunjuk adanya struktural linear dalam citra yang dimiliki sangat tinggi. Sedangkan ciri dengan nilai rata-rata rendah adalah energy karena memiliki nilai rata-rata benih Kacang Kedelai layak sebesar 0.0982 dan benih Kacang Kedelai tidak layak sebesar 0.1056 hal ini berarti keseragaman pada tekstur citra tersebut kurang.

Karakteristik ciri homogenitas pada citra Benih Kacang Kedelai layak tanam dan tidak layak tanam 
Rata-rata dari ciri homogenitas adalah 0.9241 untuk benih Kacang Kedelai layak tanam dan 0.9243 untuk benih Kacang Kedelai tidak layak tanam. Berdasarkan rata-rata pada benih layak tanam dan tidak layak tanam maka rentang nilainya tidak terlalu jauh, padahal perbedaan antara nilai ciri homogenitas akan memudahkan program dalam membedakan jenis benih layak tanam dan tidak layak tanam.

\section{Karakteristik Ciri korelasi pada Citra Benih Kacang Kedelai Layak Tanam dan tidak Layak Tanam}

Rata-rata dari ciri korelasi adalah 0.9967 untuk benih Kacang Kedelai layak tanam dan 0.9969 untuk benih Kacang Kedelai tidak layak tanam. Rata-rata yang hampir sama tersebut akan menyulitkan program untuk membedakan citra benih Kacang Kedelai.

\section{Karakteristik ciri kontras pada citra Benih Kacang Kedelai layak tanam dan tidak layak tanam}

Rata-rata dari ciri kontras adalah 0.4589 untuk benih Kacang Kedelai layak tanam dan 0.2903 untuk benih Kacang Kedelai tidak layak tanam. Perbedaan yang cukup jauh yaitu 0.1686 maka dapat memudahkan program untuk membedakan citra benih Kacang Kedelai layak dan tidak layak.

Karakteristik ciri energi pada citra Benih Kacang Kedelai layak tanam dan tidak layak tanam

Rata-rata dari ciri energy adalah 0.0982 untuk benih Kacang Kedelai layak tanam dan 0.1056 untuk benih Kacang Kedelai tidak layak tanam. Berdasarkan rata-rata pada benih layak tanam dan tidak layak tanam maka rentang nilainya terlalu jauh, padahal perbedaan antara nilai ciri energy akan memudahkan program dalam membedakan jenis benih layak tanam dan tidak layak tanam.

Pada penelitian sebelumnya yang telah dikerjakan sebelumnya digunakan klasifikasi $k$-NN dengan jarak yang digunakan adalah euclidean distance dan nilai $\mathrm{k}$ yang dipakai adalah 1 dan menggunakan ekstraksi ciri orde II atau GLCM. Skenario data yang digunakan adalah skenario empat fold validasi silang (4-fold cross validation). Hasil validasi yang didapatkan dari klasifikasi $k$-NN untuk setiap ciri adalah $63.82 \%$ untuk ciri energi, $75.5 \%$ untuk ciri homogenitas, $65.75 \%$ untuk ciri kontras, dan $78.67 \%$ untuk ciri korelasi. Validasi diulang satu kali untuk setiap ciri dan diambil rataratanya. Dari data hasil validasi didapatkan bahwa ekstraksi citra untuk membedakan benih Kacang Kedelai yang layak dan tidak layak sudah layak untuk digunakan. Untuk lebih jelasnya bisa dilihat pada perbedaan pengujian sensitivitas dan spesifisitas masing-masing ciri yang ditampilkan pada Tabel 4 sampai Tabel 7.

Tabel 4. Pengujian sensitivitas dan spesivisitas ciri homogenitas citra benih Kacang Kedelai

\begin{tabular}{cccc}
\hline Arah & Sensitivitas & Spesifisitas & Akurasi \\
\hline $0^{\circ}$ & $100 \%$ & $100 \%$ & $100 \%$ \\
$45^{\circ}$ & $32.10 \%$ & $70.83 \%$ & $51 \%$ \\
$90^{\circ}$ & $96.25 \%$ & $19.17 \%$ & $81 \%$ \\
$135^{\circ}$ & $96.25 \%$ & $19.17 \%$ & $81 \%$ \\
\hline Rata-rata & $\mathbf{8 1 . 1 5 \%}$ & $\mathbf{5 2 . 2 9} \%$ & $\mathbf{7 5 . 5 \%}$ \\
\hline
\end{tabular}

Tabel 5. Pengujian sensitivitas dan spesivisitas ciri korelasi citra benih Kacang Kedelai

\begin{tabular}{|c|c|c|c|}
\hline Arah & Sensitivitas & Spesifisitas & Akurasi \\
\hline $0^{\circ}$ & $77.5 \%$ & $40 \%$ & $48 \%$ \\
\hline $45^{\circ}$ & $100 \%$ & $100 \%$ & $100 \%$ \\
\hline $90^{\circ}$ & $100 \%$ & $17.5 \%$ & $83.67 \%$ \\
\hline $135^{\circ}$ & $100 \%$ & $17.5 \%$ & $83 \%$ \\
\hline Rerata & $85 \%$ & $53.12 \%$ & 1003 \\
\hline
\end{tabular}

Tabel 6. Pengujian sensitivitas dan spesivisitas ciri kontras citra benih Kacang Kedelai

\begin{tabular}{cccc}
\hline Arah & Sensitivitas & Spesifisitas & Akurasi \\
\hline $0^{\circ}$ & $41.10 \%$ & $80.41 \%$ & $49 \%$ \\
$45^{\circ}$ & $27.37 \%$ & $95.83 \%$ & $42 \%$ \\
$90^{\circ}$ & $100 \%$ & $100 \%$ & $100 \%$ \\
$135^{\circ}$ & $98.80 \%$ & $44.58 \%$ & $86 \%$ \\
\hline Rerata & $\mathbf{6 1 . 5 0 \%}$ & $\mathbf{8 1 . 0 4} \%$ & $\mathbf{6 5 . 7 5 \%}$ \\
\hline
\end{tabular}

Tabel 7. Pengujian sensitivitas dan spesivisitas ciri energy citra benih Kacang Kedelai

\begin{tabular}{cccc}
\hline Arah & Sensitivitas & Spesifisitas & Akurasi \\
\hline $0^{\circ}$ & $41.10 \%$ & $80.41 \%$ & $49 \%$ \\
$45^{\circ}$ & $95.23 \%$ & $40 \%$ & $84 \%$
\end{tabular}




\begin{tabular}{cccc}
$90^{\circ}$ & $45.59 \%$ & $76.35 \%$ & $52.29 \%$ \\
$135^{\circ}$ & $63.69 \%$ & $95 \%$ & $70 \%$ \\
\hline Rata-rata & $\mathbf{6 1 . 4 0 \%}$ & $\mathbf{7 2 . 9 1 \%}$ & $\mathbf{6 3 . 8 2 \%}$ \\
\hline
\end{tabular}

Dari data selanjutnya, dapat dilihat bahwa pada ciri homogenitas yaitu untuk sensitivitas sebesar $81.15 \%$, untuk spesifisitas sebesar $52.29 \%$, dan akurasi sebesar $75.5 \%$, untuk ciri korelasi yaitu untuk sensitivitas sebesar $85 \%$, untuk spesifisitas sebesar $53.12 \%$, dan akurasi sebesar $78.67 \%$, ciri kontras yaitu untuk sensitivitas sebesar $61.50 \%$, untuk spesifisitas sebesar $81.04 \%$, dan akurasi sebesar $65.75 \%$, dan ciri energy yaitu untuk sensitivitas sebesar $61.40 \%$, untuk spesifisitas sebesar $72.19 \%$, dan akurasi sebesar $63.82 \%$. Sehingga dari ke 4 ciri pada GLCM ini dapat dikatakan bahwa teknik klasifikasi dengan $k$-NN sudah memberikan hasil yang baik dalam mengklasifikasi citra dengan tekstur menggunakan ciri haralick atau GLCM.

Berikut adalah tabel rata-rata dari pengujian sensitivitas dan spesivisitas GLCM citra benih Kacang Kedelai dapat dilihat pada Tabel 8 berikut ini.

Tabel 8. Pengujian sensitivitas dan spesivisitas GLCM citra benih Kacang

\begin{tabular}{lccc}
\multicolumn{4}{c}{ Kedelai } \\
\hline \multicolumn{1}{c}{ Ciri } & Sensitivitas & Spesifisitas & Akurasi \\
\hline Homogeneity & $81.15 \%$ & $52.29 \%$ & $75.5 \%$ \\
Correlation & $85 \%$ & $53.12 \%$ & $78.67 \%$ \\
Contrast & $61.50 \%$ & $81.04 \%$ & $65.75 \%$ \\
Energy & $61.40 \%$ & $72.91 \%$ & $63.82 \%$ \\
\hline \multicolumn{1}{c}{ Rerata } & $\mathbf{7 2 . 2 7 \%}$ & $\mathbf{6 4 . 8 4 \%}$ & $\mathbf{7 0 . 9 3 \%}$ \\
\hline
\end{tabular}

Dari tabel 8 dapat dilihat bahwa rata-rata pengujian sensitivitas, spesivisitas dan akurasi untuk GLCM adalah sensitivitas $72.27 \%$, spesivisitas $64.84 \%$ dan akurasi $70.93 \%$.

Dari kedua hasil pengujian klasifikasi pada tabel diatas yang digunakan yaitu ekstraksi ciri statistik orde I (color moment) dan ekstraksi ciri statistik orde II (GLCM) menggunakan klasifikasi $k$-NN dengan jarak euclidean distance untuk pemilihan benih Kacang Kedelai maka dapat dibandingkan bahwa ekstraksi yang paling baik untuk digunakan adalah ekstraksi ciri statistik orde I (color moment) dengan nilai akurasinya mencapai $88 \%$ sedangkan ekstraksi ciri statistik orde II (GLCM) dengan nilai akurasinya mencapai $70.93 \%$. Sehingga dapat disimpulkan bahwa teknik klasifikasi dengan $k$-NN sudah memberikan hasil yang baik dalam mengklasifikasi citra dengan ciri statistik orde I (color moment) dan ciri statistik orde II (GLCM).

\section{KESIMPULAN}

Pada penelitian untuk pemilihan benih jagung lokal Pulau Timor Provinsi Nusa Tenggara Timur khusunya di Kampung Masik, Desa Numponi, Malaka dengan ekstraksi ciri statistik orde I menunjukkan bahwa pada ciri mean, standar deviasi dan skewness memiliki validasi rata-rata sebesar $88 \%$ dan ekstraksi ciri statistik orde II menunjukkan bahwa pada ciri homogenitas, korelasi, kontras dan energy memiliki validasi ratarata sebesar $70.93 \%$. Dari hasil tersebut dapat disimpulkan bahwa ekstraksi ciri statistik orde I lebih baik dari ekstraksi ciri statistik orde II dalam mengklasifikasikan citra ke dalam kelas benih layak tanam dan kelas benih tidak layak tanam.

\section{DAFTAR PUSTAKA}

[1] [BPS] BPS Indonesia.2016. Statistik Pertanian NTT. Kupang [ID]: BPS

[2] Hakim DD. 2016. Keragaan Agronomian Produksi Tiga Varietas Kedelai Tipe Baru dengan Pengaruh Variasi Jumlah Bibit dan Pemupukan Silika Di Kabupaten Indramayu. [Skripsi]. Bogor [ID]: Institut Pertanian Bogor.

[3] Han, J Kamber, M Pei. 2012. Data Mining Concept and Technique. Ed. 3. Waltham [US]: Morgan Kaufman.

[4] Medjahed S, A Saadi, TA Benyettou. 2013.Breast Cancer Diagnosis By Using k-Nearest Neighbor with Different Distances and Classification Rules. International Journal of Computer Application. Vol.62. Ed, 1, hal 1-5.

[5] Litbang pertanian 2016

[6] Permatasari D.2012. Sistem Klasifikasi Kualitas Biji Kacang Kedelai Berdasarkan Tekstur Berbasis Pengolahan Citra Digital. [Skripsi]. Bandung [ID]: Institut 
Teknologi Telkom.

[7] Pollo, LD. 2016. Perbandingan Pengukuran Jarak Dalam Penentuan Kualitas Benih Kacang Kedelai Lokal Pulau Timor dengan $k$-Nearest Neighbor. [Skripsi]. Kupang [ID]: STIKOM Uyelindo Kupang.

[8] Prasetyo E. 2012. Data Mining: Konsep dan Aplikasi Menggunakan Matlab. Yogyakarta [ID]: Andi.

[9] Putra JA.2014. Implementasi $k$-Nearest Neighbor untuk Klasifikasi Kualitas Tembakau Menggunakan Digital Image Processing Berbasis Android. [Skripsi]. Jember [ID]: Universitas Jember.

[10] Tampani A. 2016. Perbandingan Ekstraksi Tekstur Citra dengan metode Statistik Orde I dan Statistik Orde II untuk Pemilihan Benih Kacang Kedelai. [Skripsi]. Kupang [ID]: STIKOM Uyelindo Kupang.

[11] Kaesmetan Yampi 2018. Ekstraksi Ciri Benih Kacang Kedelai Dengan Klasifikasi K-Nearest Neighbor, Jurnal HOAQ Teknologi Informasi Volume 9 Nomor 1, Mei Halaman 816.

[12] Yusuf, Pohan, A. Syamsuddin. 2013. Kacang Kedelai Makanan Pokok untuk Mendukung Ketahanan Pangan Di Provinsi Nusa Tenggara Timur. Sulawesi Selatan.

[13] Zhu, S. Dong, W. \& Liu, W. 2015. Hierarchical Reinforcement Learning Based on KNN Classification Algorithms. International Journal of Hybrid Information Technology. Jurnal Volume ke-8. Halaman 175-184. 